\title{
Functional Characteristics and Molecular Identification of Interspecific Hybrids from Genus Capsicum
}

\author{
Dorota Olszewska $^{1, *(\mathbb{D}, \text { Magdalena Tomaszewska-Sowa }}{ }^{2}$, Emilia Witkowska ${ }^{3}$ and Jakub Litewka $^{3}$ \\ 1 Department of Agricultural Biotechnology, Faculty of Agriculture and Biotechnology, \\ Bydgoszcz University of Science and Technology, Prof. S. Kaliskiego 7 Street, 85-796 Bydgoszcz, Poland \\ 2 Department of Agricultural Biotechnology, Faculty of Agriculture and Biotechnology, \\ Bydgoszcz University of Science and Technology, Bernardyńska 6/8 Street, 85-029 Bydgoszcz, Poland; \\ magda@utp.edu.pl \\ 3 Doctorate School, Bydgoszcz University of Science and Technology, Prof. S. Kaliskiego 7 Street, \\ 85-796 Bydgoszcz, Poland; emiwit001@utp.edu.pl (E.W.); jaklit001@utp.edu.pl (J.L.) \\ * Correspondence: dorota@utp.edu.pl; Tel.: +48-52-340-80-19
}

Citation: Olszewska, D.;

Tomaszewska-Sowa, M.; Witkowska,

E.; Litewka, J. Functional

Characteristics and Molecular Identification of Interspecific Hybrids from Genus Capsicum. Agriculture 2021, 11, 1198. https://doi.org/ 10.3390/agriculture11121198

Academic Editor: Justyna Cybulska

Received: 6 October 2021

Accepted: 24 November 2021

Published: 27 November 2021

Publisher's Note: MDPI stays neutral with regard to jurisdictional claims in published maps and institutional affiliations.

Copyright: (c) 2021 by the authors. Licensee MDPI, Basel, Switzerland. This article is an open access article distributed under the terms and conditions of the Creative Commons Attribution (CC BY) license (https:// creativecommons.org/licenses/by/ $4.0 /)$.

\begin{abstract}
The taxonomy of the genus Capsicum has distinguished more than twenty species of peppers with only $C$. annuum L. being a vegetable of economic importance. The remaining species can, however, be used in breeding via interspecies hybridization as a source of valuable functional traits. The aim of the study was to obtain interspecific hybrids of peppers with increased agronomic potential and their molecular identification. Based on their agromorphological characteristics, the obtained hybrids ('Anchi' $\times$ C. frutescens $\left.\mathrm{L}_{\text {. }}\right) \mathrm{F}_{1}$ and ('Anchi' $\times$ C. baccatum var. pendulum $) \mathrm{F}_{1}$ formed fruits that had the combined functional traits typical of the cultivar 'Anchi', with a high content of soluble solids and dry matter characteristic of pollinators. To identify hybrids and their parental forms, the random amplified polymorphic DNA polymerase chain reaction (PCR-RAPD) and inter simple sequence repeat polymerase chain reaction (PCR-ISSR) techniques were used. The polymorphic products obtained in both methods totalled $65 \%$ and $59 \%$, respectively, and they allowed for the identification of all tested genotypes, excluded the possibility of self-pollination of 'Anchi' plants, and confirmed the hybrid characteristics of the crossbreed ('Anchi' $\times$ C. frutescens $\left.\mathrm{L}_{\text {. }}\right) \mathrm{F}_{1}$.
\end{abstract}

Keywords: PCR-RAPD method; PCR-ISSR method; agromorphological traits; C. baccatum var. pendulum; C. frutescens L.; C. chinense Jacq.

\section{Introduction}

The genus Capsicum is native to tropical and subtropical areas of Middle and Central America. Contemporary taxonomy has identified more than twenty Capsicum species, five of which are considered domesticated, including C. annuum, C. baccatum, C. chinense, C. frutescens, and C. pubescens [1]. Among these, only C. annuum L. is a vegetable of major economic importance [2], and it has been widely spread and cultivated all over the world [3]. Pepper fruits are appreciated by consumers because of their high nutritional values of vitamins and minerals as well as for their unique taste and aroma. This positive impact makes the pepper a functional food that also plays an important role in the prevention of many diseases due to their antiseptic, anti-inflammatory, and antioxidant properties. Natural pigments obtained from pepper fruits are used not only as food colourings and flavour enhancers, but also in the cosmetic and pharmaceutical industries. The increased agronomic potential of pepper genotypes in such a diverse scope can be obtained by interspecific hybridization. It is an effective tool for introducing resistance to diseases and pests into cultivated varieties and to extend their adaptability to adverse cultivation conditions caused by climate changes [4-7]. The diverse use of pepper fruits also generates a demand for variants with increased fruit suitability for industrial processing, characterized by a high content of capsaicinoids, vitamin C, and other bioactive chemical compounds. Wild-type 
species of the genus Capsicum can also be a source of these desired ingredients [8]. In the case of interspecific hybrids, it has been emphasized that the components require proper selection for hybridization, which is necessary for avoiding interspecific incompatibility. The existing barriers have resulted primarily from genetic distance and mutual relations within the genus Capsicum. Contemporary taxonomy distinguishes three systematic groups, the first of which is $C$. annuum complex including $C$. frutescens, $C$. chinense, $C$. chacoense, and C. galapagoense. The second group, which is more genetically distant, includes genotypes C. baccatum, C. tovarii, and C. pratermissum, while the third group comprises C. pubescens, C. eximum, and C. cardenassi [5]. Previously conducted studies have confirmed the possibility of effective crossbreeding in the cases of the less genetically distant species $C$. chinense and $C$. annuum [9] as well as $C$. chinense $\times$ C. frutescens [10]. Hybridization between these complexes has been very problematic. The transfer of the desired traits in such cases may require additional biotechnological support. Yoon et al. [11] reported successful crossings of $C$. annuum and C. baccatum using an embryo-rescue technique. Martins et al. [12] also obtained single hybrid plants by crossbreeding C. annuиm $\times$ C. baccatum, but their vitality and fertility were reduced. Yoon and Park [7] applied a crossbreeding method by introducing $C$. chinense into the first phase to reduce the genetic distance between the parental components of $C$. annuum and C. baccatum. In the presented study, the 'Anchi' cultivar derived from the hybrid (C. annuиm $\times$ C. chinense $) \mathrm{F}_{1}$ was used as the maternal form for interspecific crossings. The $C$. frutescens and $C$. baccatum species were used as pollinators in the next cycle of crossings. The aim of this study was to obtain interspecific hybrids with increased agronomic potential, constituting an attractive possibility of rapid expansion of the range of peppers' functional traits and molecular identifications of the obtained hybrids with the application of the random amplified polymorphic DNA polymerase chain reaction (PCR-RAPD) and inter simple sequence repeat polymerase chain reaction (PCR-ISSR) methods.

\section{Materials and Methods}

\subsection{Plant Material}

The maternal genotype for interspecific crossings was the 'Anchi' line, which was derived from the interspecific hybrid $\left(C\right.$. annuum $\mathrm{L} . \times C$. chinense Jacq.) $\mathrm{F}_{1}$. The $C$. frutescens $\mathrm{L}$. and $C$. baccatum var. pendulum species were used as pollinators in the next cycle of crossings. Genotypes representing paternal forms included C. chinense Jacq., C. frutescens L. and C. baccatum var. pendulum, all of which came from World Vegetable Centre in Taiwan (AVRDC). Biometric descriptions of hybrid ('Anchi' $\times$ C. frutescens) $\mathrm{F}_{1}$ and ('Anchi' $\times$ C. baccatum) $\mathrm{F}_{1}$ and their parental forms were performed in the system of three repetitions of the comparative experiment with ten plants in each repetition (Figure 1).
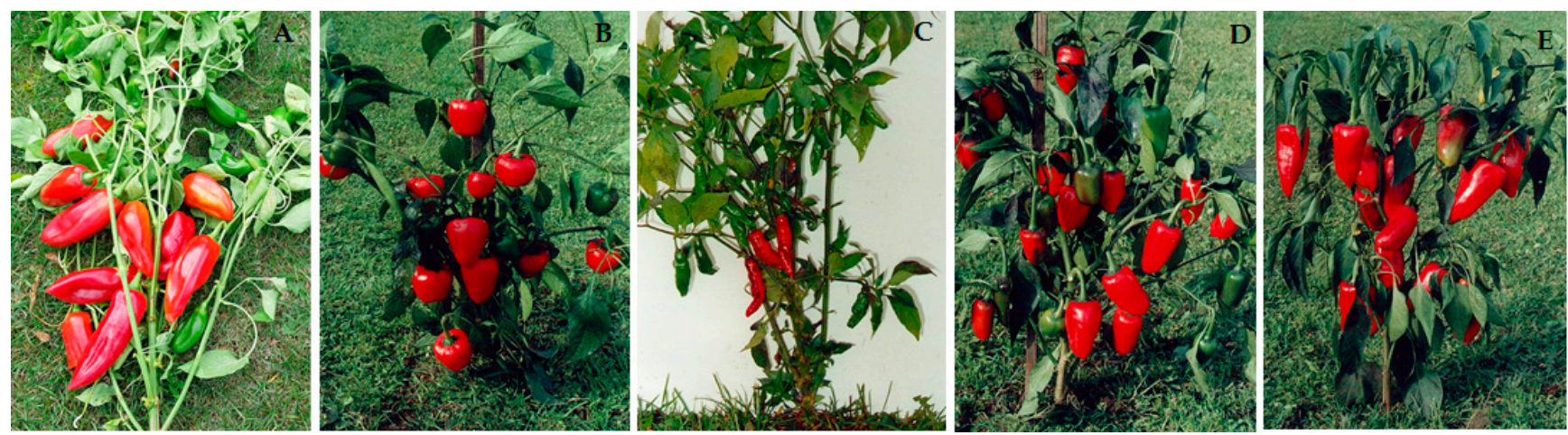

Figure 1. Plants representing the genotypes described in the experiment: 'Anchi' (A), C. frutescens L. (B), C. baccatum var. pendulum $(\mathbf{C}),($ 'Anchi' $\times$ C. frutescens $) \mathrm{F}_{1}(\mathbf{D})$, and ('Anchi' $\times$ C. baccatum $) \mathrm{F}_{1}(\mathbf{E})$.

Fruit characteristics were evaluated according to the principles given in 'Descriptors for Capsicum ssp.' (IPGRI 1995 International Plant Genetic Resources Institute, Rome, Italy). 
Five plants from each repetition were randomly selected for morphological evaluation, for which the yield and number of fruits per plant were determined. Next, three fruits from each plant were subjected to detailed biometric analysis. The following parameters were measured: fruit weight without stalk, fruit length and width, technological mass, weight of placenta with seeds, technological efficiency, wall thickness, wet seed weight, soluble solids content, and dry matter content. The technological efficiency of individual fruits was calculated as the ratio of the technological weight of the fruit to the weight of the fruit without the stalk. The thickness of the pericarp walls was measured three times in the middle part of the fruit. The dry matter was determined by drying $1.5 \mathrm{~g}$ of the pericarp at $105^{\circ} \mathrm{C}$. The extract content was determined using an Abbe optical refractometer. The achieved results were analysed statistically by means of one-way analysis of variance and Scheffé's test. Results were deemed statistically significant at $\alpha=0.05$. The cultivation of parental forms and hybrids was carried out in 2018 in unheated foil tunnels with the use of agrotechnical treatments appropriate for $C$. annuum $\mathrm{L}$. All breeding materials came from the collection at the Department of Agricultural Biotechnology, Bydgoszcz University of Science and Technology.

\subsection{Molecular Analysis}

For molecular analysis of parental and hybrid forms, $100 \mathrm{mg}$ of tissue of young, healthy leaves were taken from three randomly selected plants of each genotype. Genomic DNA isolation was conducted using GenElute Plant Genomic DNA Miniprep Kit (Sigma-Aldrich, Saint Louis, MO, USA). The purity was evaluated electrophoretically and spectrophotometrically. For DNA amplification, Taq polymerase (A\&A Biotechnology, Gdańsk, Poland) was used. Based on the previously conducted research, 26 RAPD and 24 ISSR primers (Laboratory of DNA Sequencing and Oligonucleotide Synthesis IBB PAN) were selected, which were effective in the identification of genetic differentiation of the peppers' breeding material used in this study. Their sequences and designations were taken from the literature data on molecular identification of genotypes of the genus Capsicum. The PCR reactions were carried out using the ATC401 Thermal Cycler (Nyx Technik Apollo, San Francisco, CA, USA) in a $20 \mu \mathrm{L}$ reaction volume containing $20 \mathrm{ng}$ of genomic DNA as templates, $20 \mathrm{mM} \mathrm{MgSO}_{4}, 0.25 \mu \mathrm{M}$ of primer, $200 \mu \mathrm{M}$ of each dNTPs, and 0.5 unit of Taq polymerase (A\&A Biotechnology, Gdańsk, Poland). The RAPD-PCR reaction was conducted in accordance with the method developed for C. annuum L. [13]. The initial denaturation was carried out at $91^{\circ} \mathrm{C}$ for $1 \mathrm{~min}$ and was followed by 40 cycles consisting of $15 \mathrm{~s}$ at $91^{\circ} \mathrm{C}, 15 \mathrm{~s}$ at $42^{\circ} \mathrm{C}$, and $1 \mathrm{~min} 10 \mathrm{~s}$ at $72{ }^{\circ} \mathrm{C}$. For ISSR primers, the initial denaturation was also carried out at $91^{\circ} \mathrm{C}$ for $1 \mathrm{~min}$ and followed by 40 cycles consisting of $30 \mathrm{~s}$ at $91^{\circ} \mathrm{C}$, $1 \mathrm{~min}$ at $48.5-67.2^{\circ} \mathrm{C}$ and $2 \mathrm{~min}$ at $72{ }^{\circ} \mathrm{C}$. The final extension was completed for $5 \mathrm{~min}$ at $72{ }^{\circ} \mathrm{C}$ for both RAPD and ISSR techniques. The reactions were carried out twice. The products of the PCR-RAPD and PCR-ISSR reactions were separated in $1.8 \%$ agarose gel stained with ethidium bromide. Electrophoresis was carried out for two hours at $100 \mathrm{mV}$ (Figure 2). The size of the obtained products was determined using molecular mass marker GeneRuler DNA Ladder Mix (Thermo Fisher Scientific Inc., Waltham, MA, USA) and the computer program GelAnalyzer 2010a (gelanalyzer.com). The obtained DNA fragments were visualized and recorded on a Gel Doc 2000 UV transilluminator (Bio-Rad, Hercules, CA, USA). Genetic distance between the tested genotypes was determined using the Nei and Li [14] formula. 


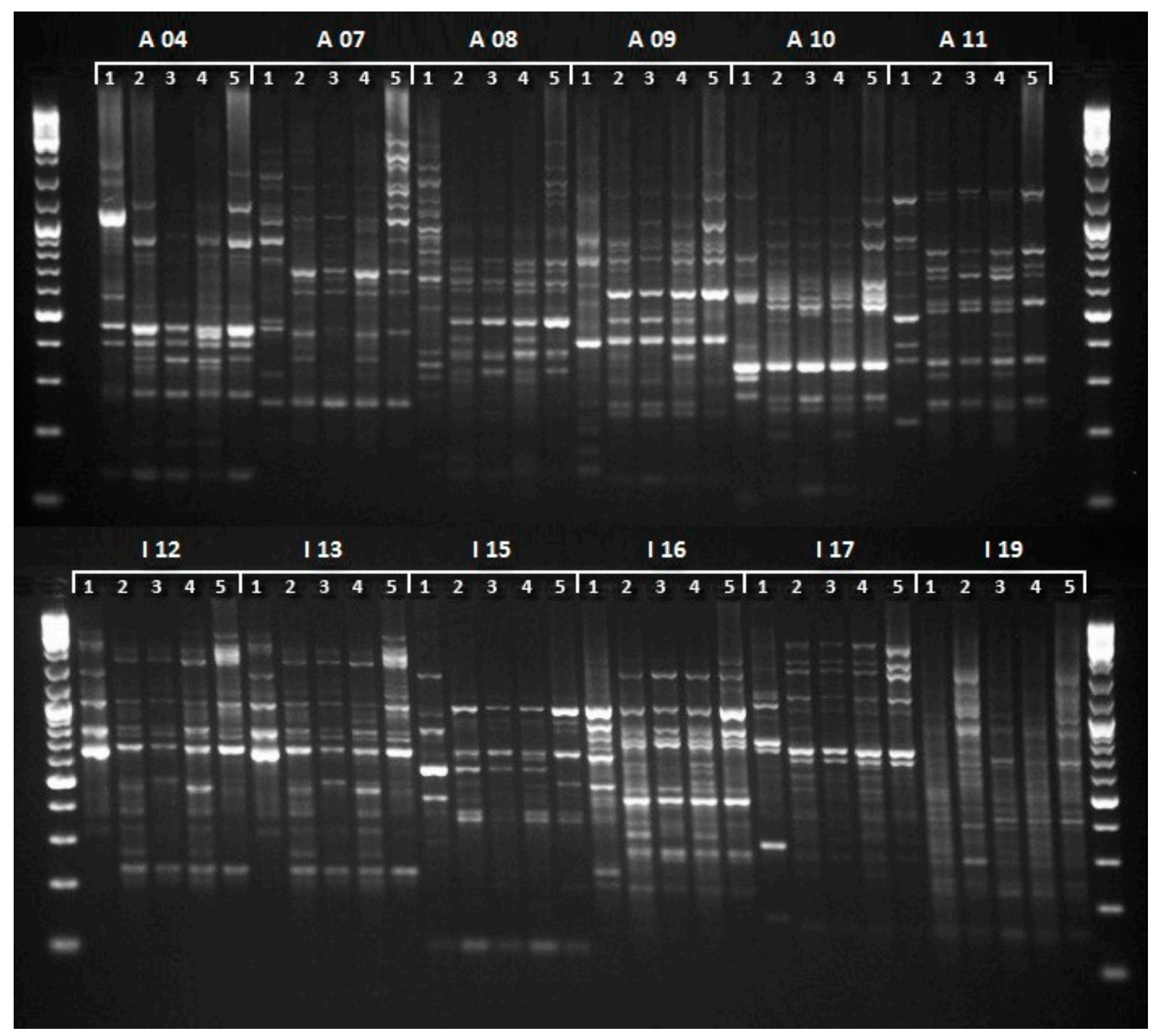

Figure 2. Products of the polymerase chain reaction (PCR) with primers: A 04, A 07, A 08, A 09, A 10, A 11, I 12, I 13, I 15, I 16, I 17, I 19; marker (M), 1. C. baccatum var. pendulum; 2. ('Anchi' $\times$ C. baccatum) $\mathrm{F}_{1}$; 3. 'Anchi'; 4. ('Anchi' $\times$ C. frutescens) $\mathrm{F}_{1}$; 5. C. frutescens L.

\section{Results and Discussion}

The unique qualities of pepper fruits, such as their rich chemical composition, taste, and aroma, make them viable as a raw material not only in the food industry but also in cosmetics and pharmaceuticals. Obtaining the desired genetic combinations that would respond to the varied needs of manufacturers could be achieved using several methods, namely by extending the existing gene pool via interspecies hybridization. The practical assessment of the hybrids obtained in this way constituted the basis for the selection of the most valuable materials. In the presented study, the assessments of parental forms and interspecies hybrids of peppers were carried out for 12 functional parameters (Table 1). Statistically significant differences were noted for all analysed traits. Both ('Anchi' $\times$ C. frutescens $) \mathrm{F}_{1}$ and ('Anchi' $\times$ C. baccatum $) \mathrm{F}_{1}$ hybrids had lower yields than the maternal line. However, in terms of the technological mass of the fruit, the wall thickness, and the weight of the fruit with the stalk, the hybrids ('Anchi' $\times$ C. baccatum) $\mathrm{F}_{1}$ were comparable to the cultivar 'Anchi'. The weight of the fruit is one of the basic functional parameters of the pepper. Individual consumers value large juicy fruits, but in the case of industrial use, excess fruit weight is not desirable as it can cause damage to the production materials. The fruits obtained in the experiment, weighing $91.45 \mathrm{~g}$ for ('Anchi' $\times$ C. bacca- 
tum) $\mathrm{F}_{1}$ and $65.06 \mathrm{~g}$ for ('Anchi' $\times$ C. frutescens) $\mathrm{F}_{1}$, seemed to be a favourable compromise between these requirements. In the case of the examined hybrids, no decrease in the share of edible parts in the fruit weight was observed. Technological performance in both hybrids was at the level of the maternal form 'Anchi'. In contrast, the biometric analysis of both hybrids demonstrated an increased content of soluble solids and dry matter in the pericarp, as compared to the maternal form. The water content in the raw material is a very important functional feature, especially for the dried fruit industry. Since the heat treatment necessary for obtaining this form of material can result in the loss of vitamin C, it is advisable to increase the dry matter content of the pericarp. In the study conducted, interspecific hybridization provided the desired variability both in the case of $($ 'Anchi' $\times$ C. baccatum $) \mathrm{F}_{1}$ and in ('Anchi' $\times$ C. frutescens $) \mathrm{F}_{1}$. Furthermore, the fruits of both hybrid forms were characterized by high seed weight and did not differ in respect to this parameter from the fruits of the parental forms that were obtained due to self-pollination. These results showed that the obtained material met the breeding requirements in terms of the fertility of the formed fruits.

Table 1. Functional characteristics of parental and hybrid genotypes of peppers.

\begin{tabular}{|c|c|c|c|}
\hline Genotype & $\begin{array}{c}\text { Fruit Number per Plant } \\
\text { Mean } \pm \text { Standard } \\
\text { Deviation }\end{array}$ & $\begin{array}{c}\text { Fruit Weight per Plant (g) } \\
\text { Mean } \pm \text { Standard } \\
\text { Deviation }\end{array}$ & $\begin{array}{c}\text { Weight of Fruit without } \\
\text { Stalk (g) Mean } \pm \text { Standard } \\
\text { Deviation }\end{array}$ \\
\hline C. baccatum & $33.6 \pm 4.9 \mathrm{~b}^{*}$ & $344.0 \pm 53.1 \mathrm{a}$ & $11.19 \pm 1.33 \mathrm{a}$ \\
\hline$($ Anchi $\times$ C. bac. $) \mathrm{F}_{1}$ & $15.4 \pm 2.7 \mathrm{a}$ & $1198.0 \pm 108.1 c$ & $91.45 \pm 6.92 c$ \\
\hline 'Anchi' & $18.8 \pm 3.5 \mathrm{a}$ & $1705.1 \pm 171.0 \mathrm{~d}$ & $111.57 \pm 15.17 c$ \\
\hline$($ Anchi $\times$ C. frut. $) \mathrm{F}_{1}$ & $14.6 \pm 4.2 \mathrm{a}$ & $822.1 \pm 110.8 b$ & $65.06 \pm 17.77 b$ \\
\hline C. frutescens & $13.0 \pm 2.5 \mathrm{a}$ & $436.6 \pm 71.7 \mathrm{a}$ & $34.93 \pm 7.47 \mathrm{ab}$ \\
\hline$p$-value & 0.00 & 0.00 & 0.00 \\
\hline Genotype & $\begin{array}{l}\text { Fruit Length }(\mathrm{mm}) \\
\text { Mean } \pm \text { Standard } \\
\text { Deviation }\end{array}$ & $\begin{array}{c}\text { Fruit Width (mm) } \\
\text { Mean } \pm \text { Standard Deviation }\end{array}$ & $\begin{array}{c}\text { Technological Mass (g) } \\
\text { Mean } \pm \text { Standard Deviation }\end{array}$ \\
\hline C. baccatum & $93.78 \pm 7.58 \mathrm{ab}$ & $16.99 \pm 1.81 \mathrm{a}$ & $9.73 \pm 1.47 \mathrm{a}$ \\
\hline$($ Anchi $\times$ C. bac. $) \mathrm{F}_{1}$ & $113.62 \pm 13.94 c$ & $54.83 \pm 7.09 \mathrm{~b}$ & $77.62 \pm 6.53 \mathrm{bc}$ \\
\hline 'Anchi' & $141.23 \pm 7.15 \mathrm{~d}$ & $57.11 \pm 5.76 b$ & $99.15 \pm 15.59 c$ \\
\hline$($ Anchi $\times$ C. frut. $) \mathrm{F}_{1}$ & $106.81 \pm 12.16 c$ & $47.23 \pm 7.13 b$ & $55.99 \pm 15.59 b$ \\
\hline C. frutescens & $75.56 \pm 10.02 \mathrm{a}$ & $45.38 \pm 6.91 b$ & $24.49 \pm 13.01 \mathrm{a}$ \\
\hline$p$-value & 0.00 & 0.00 & 0.00 \\
\hline Genotype & $\begin{array}{l}\text { Weight of Placenta with } \\
\text { Seeds (g) } \\
\text { Mean } \pm \text { Standard } \\
\text { Deviation }\end{array}$ & $\begin{array}{c}\text { Technological Efficiency } \\
\text { Mean } \pm \text { Standard } \\
\text { Deviation }\end{array}$ & $\begin{array}{l}\text { Wall Thickness }(\mathrm{mm}) \\
\quad \text { Mean } \\
\pm \text { Standard Deviation }\end{array}$ \\
\hline C. baccatum & $0.95 \pm 0.21 \mathrm{a}$ & $0.88 \pm 0.01 b$ & $1.72 \pm 0.17 \mathrm{a}$ \\
\hline$($ Anchi $\times$ C. bac. $) \mathrm{F}_{1}$ & $13.48 \pm 3.65 c$ & $0.87 \pm 0.01 b$ & $4.74 \pm 0.46 c$ \\
\hline 'Anchi' & $12.10 \pm 0.63 b c$ & $0.89 \pm 0.02 b$ & $5.18 \pm 0.45 c$ \\
\hline$($ Anchi $\times$ C. frut. $) \mathrm{F}_{1}$ & $8.49 \pm 3.10 \mathrm{~b}$ & $0.85 \pm 0.01 b$ & $3.22 \pm 0.36 b$ \\
\hline C. frutescens & $7.35 \pm 1.39 b$ & $0.78 \pm 0.04 \mathrm{a}$ & $3.18 \pm 0.52 b$ \\
\hline$p$-value & 0.00 & 0.00 & 0.00 \\
\hline \multirow{3}{*}{ Genotype } & Weight of Seeds per Fruit (g) & Soluble Solids & Dry Matter (g) \\
\hline & Mean \pm Standard & Mean & Mean \\
\hline & Deviation & \pm Standard Deviation & \pm Standard Deviation \\
\hline C. baccatum & $1.05 \pm 0.18 \mathrm{a}$ & $9.55 \pm 0.63 b$ & $13.13 \pm 0.95 b$ \\
\hline$($ Anchi $\times$ C. bac. $) \mathrm{F}_{1}$ & $2.82 \pm 0.61 b$ & $8.94 \pm 0.54 b$ & $11.33 \pm 1.26 b$ \\
\hline 'Anchi' & $2.29 \pm 0.32 b$ & $6.80 \pm 0.27 \mathrm{a}$ & $8.59 \pm 0.47 \mathrm{a}$ \\
\hline$($ Anchi $\times$ C. frut. $) \mathrm{F}_{1}$ & $2.30 \pm 0.51 b$ & $9.18 \pm 0.73 b$ & $12.17 \pm 0.73 b$ \\
\hline C. frutescens & $2.52 \pm 0.36 \mathrm{~b}$ & $8.79 \pm 1.56 b$ & $12.93 \pm 2.24 b$ \\
\hline$p$-value & 0.00 & 0.00 & 0.00 \\
\hline
\end{tabular}


Conventional methods describing agromorphological features of pepper plants and fruits were the basis for the analysis of the potential utility of the studied genotypes. However, due to the constraints resulting from the variability of phenotypes depending on the stage of plant development and the environmental impact, traditional methods are typically not perceived as a separate tool for identifying breeding materials. To assess and identify the examined form, the data had to be supplemented with cytogenetic or molecular analysis. For this reason, many researchers have applied markers based on the PCR techniques as it is an effective, efficient, and affordable solution. Among them, the analysis of DNA polymorphism with the use of RAPD and ISSR primers has been successfully used for many species of crops, including the cultivation of peppers. Costa et al. [15] used 8 RAPD primers to assess 70 genotypes of Capsicum spp., 17 of which were forms not botanically characterized. The conducted analyses verified the genetic relationships between known genotypes and allowed for the classification of the six unknowns as $C$. baccatum and five others as $C$. chinense. The high efficiency of the RAPD technique and the level of polymorphism bands at $96 \%$ were also confirmed in the study by Orenthung and Sapu [16], who analysed the genetic diversity of 16 cultivated populations of the species $C$. chinense, $C$. frutescens, and C. annuum. The RAPD technique has also been used to identify hybrid forms of Capsicum spp. Shi and Hu [17] used this system to confirm the hybrid origin of plants obtained from crossing C. annuum and C. chinense plants. The results of the experiment not only documented the hybrid nature of the studied forms, but also assisted in locating the genes related to the colour of the fruit and the content of the anthocyanins. The variability of the genotypes used in the above-mentioned studies was at the species level, but the PCR-RAPD technique was also successfully used to assess the genetic diversity within C. annuum. Ilbi et al. [18] used 12 RAPD primers, and 6 of them generated 11 polymorphic products that enabled the cultivar and hybrid identification in C. annuиm. Similar results were obtained by Bhadragoudar and Patil [19] in a study conducted on 45 genotypes of $C$. annuum. The authors used 16 RAPD primers and obtained 99 products, of which 63 were differentiated (63\%). Conversely, Tilahun et al. [20], using 20 primers in the analysis of $30 \mathrm{C}$. annuum genotypes, obtained 78 products, of which only 13 were monomorphic. However, when analysing the genetic relationships of closely related organisms, alternative molecular techniques may be needed for their identification. One such alternative system was the analysis of inter simple sequence repeat polymorphism. ISSR primers were successfully used by Ahmed [21] to identify hybrids of C. annuum and C. frutescens. As a result of the reaction with 10 starters, the ISSR obtained 52 polymorphic bands among 87 amplification products. Lijun and Xuexiao [22], while extending the pool of studied genotypes to include $C$. chinense and C. baccatum with the use of 15 primers, obtained differentiated products, which constituted $75 \%$ of the obtained total. The observed polymorphism was the basis for qualifying the $C$. annuum species to one group as well as C. baccatum and C. pubescens to a separate cluster.

The widespread use of molecular analyses due to their simplicity, low DNA consumption, and low costs have resulted the combination of various techniques that have obtained unambiguous and reproducible results or to extend their spectrum of applications. In a study of the diversity of 22 genotypes of $C$. annuum, C. baccatum, C. chinense, C. eximum, C. luteumi, and C. frutescens species, Thul et al. [23] obtained reproducible results for 27 out of 40 RAPD primers. As an alternative, the authors used 13 ISSR primers, 8 of which provided unambiguous and reproducible results. The polymorphism generated by both primer groups did not differ significantly with $67 \%$ for RAPD markers and $62 \%$ for ISSR; however, the authors indicated the ISSR technique as more effective, although both techniques made it possible to achieve the objectives of the experiment. Lower rates of polymorphism were obtained in the research of Shapturenko et al. [24]. DNA amplification products of 10 C. annuum lines with a set of 21 primers revealed a polymorphism of $26 \%$. As a support for the RAPD technique, the authors used the ISSR marker system. The obtained polymorphism remained at a similar level (29\%); however, similar to the results of Thul et al. [23], the second method was found to be more effective. 
In the presented research, 30 RAPD and ISSR primers were tested, among which 26 and 24 were selected that generated repeatable products. As a result of the reactions conducted with the RAPD primers, 280 loci were obtained, 182 of which had polymorphic characteristics. The number of bands generated per primer varied from 6 (A 13) to 16 (A 8). The approximate size of the amplified products ranged from 106 to $259 \mathrm{bp}$. Therefore, the percentage of polymorphism varied between $41.7 \%$ (P 13) and 85.7\% (A 3), with an average of $65 \%$ (Table 2). The reactions carried out using ISSR primers resulted in the amplification of 195 loci, and 115 of those were polymorphic (Table 3). The percentage of polymorphism generated by the ISSR starter varied between 33.3\% (I 40, I 71) and 85.7\% (I 73), with an average of 59\%. The number of bands generated per primer was from 4 (I 11) to 14 (I 12), and the approximate size of the amplified products ranged from 123 to $1832 \mathrm{bp}$. Based on the results of the PCR reaction, the genetic distance coefficients for the studied genotypes were calculated.

In the case of the RAPD technique (Table 4), the lowest value of the distance coefficient (0.381) was observed for hybrids ('Anchi' $\times$ C. frutescens) $\mathrm{F}_{1}$ and ('Anchi' $\times$ C. baccatum) $\mathrm{F}_{1}$. The ISSR marker (Table 5) showed the smallest genetic distance (0.222) between the 'Anchi' maternal form and the hybrid ('Anchi' $\times$ C. frutescens) $\mathrm{F}_{1}$. Both molecular techniques confirmed the highest values of genetic distance between C. baccatum var. pendulum and the other assessed genotypes. The obtained results confirmed the close affinity of interspecies hybrids and the 'Anchi' mother plants as well as the smaller genetic distance between the genotypes and the pollinator C. frutescens L., as compared to C. baccatum var. pendulum. A similar relationship regarding lower genetic differentiation in the group of hybrids and the mother form, as compared to the pollinators used in the study, was also shown by the results of distant crossings carried out by Sikora and Nowaczyk [25].

Table 2. Characteristics of the primers used in the random amplified polymorphic DNA polymerase chain reaction (PCR-RAPD).

\begin{tabular}{|c|c|c|c|c|c|}
\hline Primer & Sequence & $\begin{array}{l}\text { Number } \\
\text { of Products }\end{array}$ & $\begin{array}{c}\text { Range of } \\
\text { Product Size }\end{array}$ & $\begin{array}{l}\text { Polymorphic } \\
\text { Products }\end{array}$ & $\begin{array}{c}\% \text { of } \\
\text { Polymorphism }\end{array}$ \\
\hline A 03 & AGTCAGCCAC & 7 & $288-1254 \mathrm{bp}$ & 6 & 85.7 \\
\hline A 04 & AATCGGGCTG & 13 & $135-1899 \mathrm{bp}$ & 10 & 76.9 \\
\hline A 05 & AGGGGTCTTG & 8 & $116-1002$ bp & 6 & 75.0 \\
\hline A 06 & GGTCCCTGAC & 7 & $167-1382$ bp & 5 & 71.4 \\
\hline A 07 & GAAACGGGTG & 13 & $234-2396 \mathrm{bp}$ & 11 & 84.6 \\
\hline A 08 & GTGACGTAGG & 16 & $253-2386 \mathrm{bp}$ & 11 & 68.8 \\
\hline A 09 & GGGTAACGCC & 14 & $132-1774 \mathrm{bp}$ & 10 & 71.4 \\
\hline A 10 & GTGATCGCAG & 9 & $123-1421 \mathrm{bp}$ & 6 & 66.7 \\
\hline A 11 & CAATCGCCGT & 14 & $240-1487 \mathrm{bp}$ & 9 & 64.3 \\
\hline A 12 & TCGGCGATAG & 8 & $249-1540 \mathrm{bp}$ & 4 & 50.0 \\
\hline A 13 & CAGCACCCAC & 6 & $186-1018$ bp & 3 & 50.0 \\
\hline A 14 & TCTGTGCTGG & 10 & $251-1295 \mathrm{bp}$ & 6 & 60.0 \\
\hline A 15 & TTCCGAACCC & 11 & $182-1827$ bp & 7 & 63.6 \\
\hline A 16 & AGCCAGCGAA & 13 & $173-2581 \mathrm{bp}$ & 9 & 69.2 \\
\hline A 17 & GACCGCTTGT & 8 & $204-2391 \mathrm{bp}$ & 4 & 50.0 \\
\hline A 18 & AGGTGACCGT & 13 & $112-1256 \mathrm{bp}$ & 8 & 61.5 \\
\hline A 19 & CAAACGTCGG & 9 & $196-1688 \mathrm{bp}$ & 5 & 55.5 \\
\hline AB 09 & GGGCGACTAC & 7 & $265-1995 \mathrm{bp}$ & 4 & 57.1 \\
\hline AE 02 & GGTGCGGGAA & 11 & $191-2394$ bp & 8 & 72.7 \\
\hline AE 10 & CTGAAGCGCA & 11 & $212-2154 b p$ & 6 & 54.5 \\
\hline $\mathrm{AE} 11$ & AAGAACGGGA & 12 & $106-2040 \mathrm{bp}$ & 8 & 66.7 \\
\hline AE 19 & ACGGCGTATG & 12 & $295-2482 \mathrm{bp}$ & 9 & 76.9 \\
\hline AF 05 & CCGAATTCCC & 9 & $224-2591 \mathrm{bp}$ & 6 & 66.7 \\
\hline C 15 & GACGGATCAG & 13 & $196-2118 \mathrm{bp}$ & 8 & 61.5 \\
\hline D 12 & CACCGTATCC & 14 & $265-1106 \mathrm{bp}$ & 8 & 57.1 \\
\hline P 13 & CGAGTGCCTC & 12 & $167-1840 \mathrm{bp}$ & 5 & 41.7 \\
\hline Total & 26 RAPD primers & 280 & $106-2591 \mathrm{bp}$ & 182 & 65.0 \\
\hline
\end{tabular}


Table 3. Characteristics of the primers used in the inter simple sequence repeat polymerase chain reaction (PCR-ISSR).

\begin{tabular}{|c|c|c|c|c|c|}
\hline Primer & Sequence & $\begin{array}{l}\text { Number } \\
\text { of Products }\end{array}$ & $\begin{array}{c}\text { Range of } \\
\text { Product Size }\end{array}$ & $\begin{array}{l}\text { Polymorphic } \\
\text { Products }\end{array}$ & $\begin{array}{c}\% \text { of } \\
\text { Polymorphism }\end{array}$ \\
\hline I 1 & $(\mathrm{GA})_{8} \mathrm{YC}$ & 5 & $221-562 \mathrm{bp}$ & 3 & 60.0 \\
\hline I 10 & $(\mathrm{GA})_{8} \mathrm{YT}$ & 6 & $203-896$ bp & 5 & 83.3 \\
\hline I 11 & $(\mathrm{CT})_{8} \mathrm{GC}$ & 4 & $508-843 \mathrm{bp}$ & 3 & 75.0 \\
\hline I 12 & $(\mathrm{GACA})_{4} \mathrm{~A}$ & 14 & $126-2116 \mathrm{bp}$ & 8 & 57.1 \\
\hline I 13 & $(\mathrm{AG})_{8} \mathrm{YC}$ & 12 & $176-1740 \mathrm{bp}$ & 5 & 41.7 \\
\hline I 14 & $(\mathrm{AG})_{8} \mathrm{~T}$ & 5 & $217-777$ bp & 3 & 60.0 \\
\hline I 15 & $(\mathrm{CTC})_{4} \mathrm{YC}$ & 13 & 219-2013 bp & 8 & 61.5 \\
\hline I 16 & $(\mathrm{AG})_{8} \mathrm{C}$ & 13 & $232-2561 b p$ & 9 & 69.2 \\
\hline I 17 & $(\mathrm{TGAG})_{4}$ & 8 & $234-2591 \mathrm{bp}$ & 4 & 50.0 \\
\hline I 19 & $(\mathrm{GAG})_{3} \mathrm{GG}$ & 9 & $156-1681 \mathrm{bp}$ & 5 & 55.5 \\
\hline I 21 & $(\mathrm{AC})_{8} \mathrm{CT}$ & 10 & $273-963$ bp & 6 & 60.0 \\
\hline I 25 & $(\mathrm{CA})_{8} \mathrm{AGT}$ & 7 & $494-1385 \mathrm{bp}$ & 4 & 57.1 \\
\hline I 26 & $(\mathrm{CA})_{8} \mathrm{AT}$ & 6 & $345-832$ bp & 3 & 50.0 \\
\hline I 27 & $(\mathrm{GA})_{8} \mathrm{CT}$ & 5 & 189-989 bp & 2 & 40.0 \\
\hline I 28 & $(\mathrm{CA})_{8} \mathrm{G}$ & 6 & $225-536 \mathrm{bp}$ & 5 & 83.3 \\
\hline I 33 & $(\mathrm{GA})_{8} \mathrm{CTC}$ & 11 & $228-1197 \mathrm{bp}$ & 8 & 72.7 \\
\hline I 40 & $(\text { GGAGA) })_{4}$ & 6 & $219-1263 \mathrm{bp}$ & 2 & 33.3 \\
\hline I 46 & $(\mathrm{GA})_{8} \mathrm{~T}$ & 8 & $274-1438 \mathrm{bp}$ & 6 & 75.0 \\
\hline I 50 & $(\mathrm{ATG})_{6}$ & 6 & $251-962$ bp & 3 & 50.0 \\
\hline I 56 & $(\mathrm{GA})_{8} \mathrm{G}$ & 7 & $180-1832$ bp & 4 & 57.1 \\
\hline I 63 & $(\mathrm{CCCT})_{4}$ & 9 & $396-1122$ bp & 6 & 66.7 \\
\hline I 65 & $(\mathrm{GA})_{8} \mathrm{C}$ & 6 & $123-964$ bp & 3 & 50.0 \\
\hline I 71 & $(\mathrm{GT})_{8} \mathrm{TG}$ & 12 & $285-739 \mathrm{bp}$ & 4 & 33.3 \\
\hline I 73 & $(\mathrm{GT})_{8} \mathrm{CG}$ & 7 & 255-1473 bp & 6 & 85.7 \\
\hline Total & 24 ISSR primers & 195 & $123-1832$ bp & 115 & 59.0 \\
\hline
\end{tabular}

Table 4. Genetic distance coefficients based on RAPD markers.

\begin{tabular}{|c|c|c|c|c|c|}
\hline Genotypes & $\mathbf{F}^{*}$ & B & $\mathbf{A B}$ & A & AF \\
\hline F-C. frutescens & $x$ & & & & \\
\hline B-C. baccatum & 0.717 & $\times$ & & & \\
\hline $\mathrm{AB}-\left({ }^{\prime}\right.$ Anchi' $\times$ C. baccatum $) \mathrm{F}_{1}$ & 0.537 & 0.737 & $\times$ & & \\
\hline A-'Anchi' & 0.476 & 0.755 & 0.482 & $\times$ & \\
\hline $\mathrm{AF}-\left({ }^{\prime}\right.$ Anchi' $\times$ C. frutescens $) \mathrm{F}_{1}$ & 0.452 & 0.718 & 0.381 & 0.439 & $\times$ \\
\hline
\end{tabular}

Table 5. Genetic distance coefficients based on ISSR markers.

\begin{tabular}{|c|c|c|c|c|c|}
\hline Genotypes & $\mathbf{F}^{*}$ & B & $\mathbf{A B}$ & $\mathbf{A}$ & AF \\
\hline F-C. frutescens & $x$ & & & & \\
\hline B-C. baccatum & 0.489 & $x$ & & & \\
\hline $\mathrm{AB}-\left({ }^{\prime}\right.$ Anchi' $\times$ C. baccatum $) \mathrm{F}_{1}$ & 0.431 & 0.514 & $x$ & & \\
\hline $\mathrm{A}-{ }^{\prime} A \mathrm{nchi}^{\prime}$ & 0.337 & 0.578 & 0.292 & $x$ & \\
\hline $\mathrm{AF}-\left({ }^{\prime}\right.$ Anchi' $\times$ C. frutescens $) \mathrm{F}_{1}$ & 0.281 & 0.510 & 0.283 & 0.222 & $\times$ \\
\hline
\end{tabular}

The graphic images of the observed dependencies were dendrograms and were constructed using the UPGMA (unweight pair group method with arithmetic average) clustering algorithm. Both molecular techniques grouped the genotypes into two clusters (Figures 3 and 4). The first cluster contained the maternal form 'Anchi' and both hybrids ('Anchi' $\times$ C. frutescens $) \mathrm{F}_{1}$ and ('Anchi' $\times$ C. baccatum $) \mathrm{F}_{1}$ as well as $C$. frutescens $\mathrm{L}$. The species $C$. baccatum var. pendulum was in the second group. The results of the study demonstrated that both the RAPD and ISSR markers are an effective tool in the study of genetic diversity among Capsicum genotypes. However, for the correct inference, the selection of 
an appropriate number of primers generating polymorphic products was key. In the case of the hybrid ('Anchi' $\times$ C. frutescens $) \mathrm{F}_{1}$, the presence of specific products characteristics for the pollinator confirmed the hybrid nature of the obtained plants. However, in the case of the hybrid ('Anchi' $\times$ C. baccatum) $\mathrm{F}_{1}$, the molecular techniques applied distinguished it from its mother form and excluded emergence as a result of self-pollination of the 'Anchi' plants. Regardless of the molecular technique, the individual polymorphism of individual primers was a decisive factor in the proper assessment of the polymorphism of the studied genotypes. This relationship has been illustrated by many of the aforementioned publications $[16,19,21,23]$. In this study, there was also a differentiation of the polymorphism of the primers used, in the range of $42-86 \%$ for the RAPD system and $33-86 \%$ for the ISSR markers. Therefore, the preparation of identification experiments with the application of the molecular systems should be based on the available literature data with particular emphasis on the appropriate selection of primers.

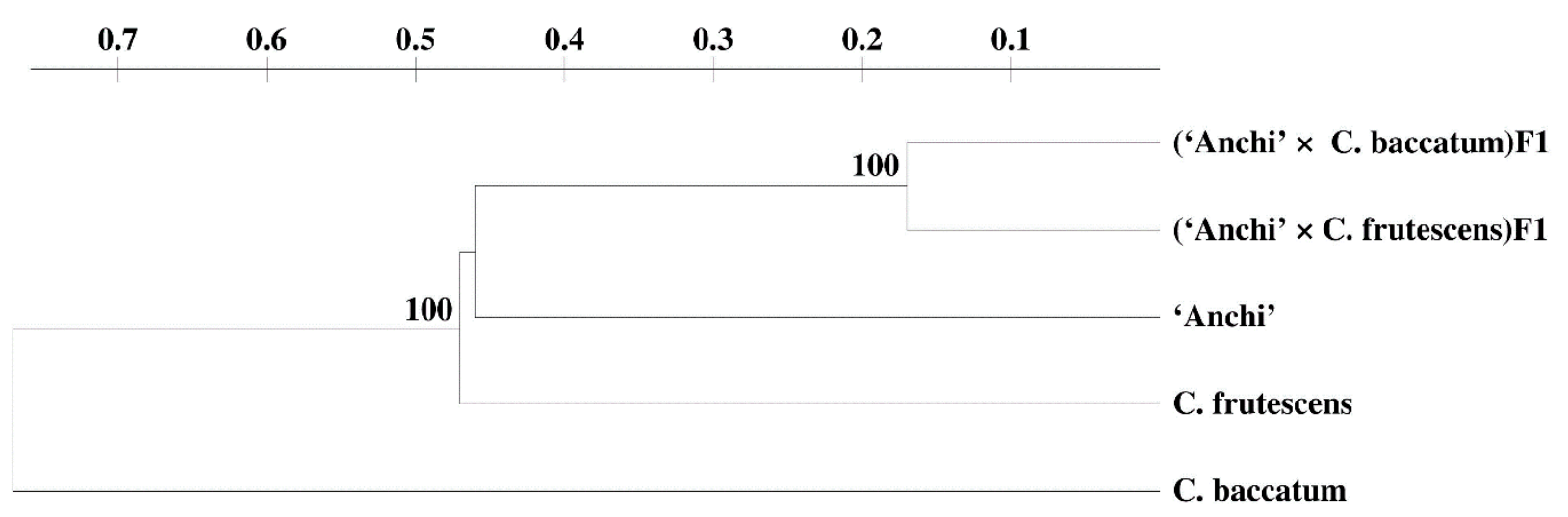

Figure 3. The UPGMA (unweight pair group method with arithmetic average) dendrogram computed using genetic-distance matrix based on RAPD markers.

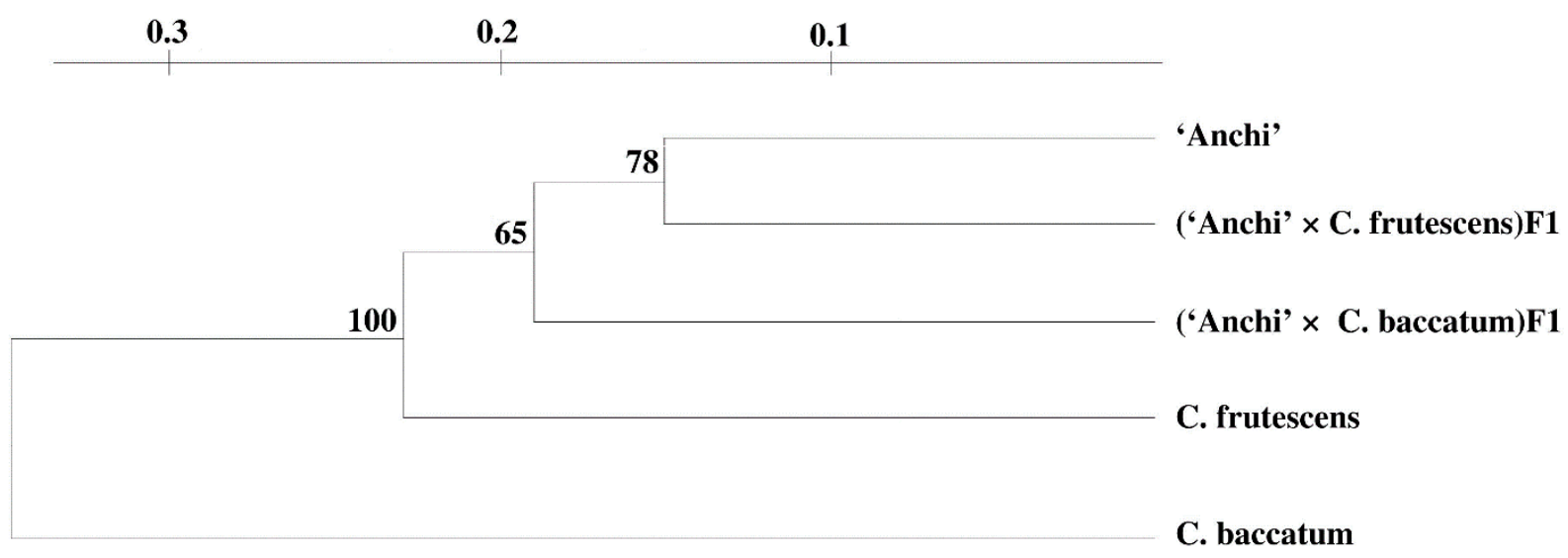

Figure 4. The UPGMA dendrogram computed using genetic-distance matrix based on ISSR markers.

The results of the conducted analyses showed that interspecific hybridization within the Capsicum genus provided variability that may be useful in breeding new varieties with original properties. For the tested genotypes: ('Anchi' $\times$ C. baccatum) $\mathrm{F}_{1}$ and ('Anchi' $\times$ C. frutescens $) \mathrm{F}_{1}$, it was especially valuable to combine the functional traits typical of the cultivar 'Anchi' with a high content of soluble solids and dry matter characteristic of pollinators. At the same time, both the RAPD and ISSR molecular techniques applied were a source of polymorphic products that enabled the identification of all the analysed genotypes, excluding the possibility of self-pollination of the 'Anchi' plants and in the case of the hybrid ('Anchi' $\times$ C. frutescens $) \mathrm{F}_{1}$, whose origin was confirmed as a result of interspecies hybridization. 
Author Contributions: Conceptualization, D.O.; methodology, D.O. and M.T.-S.; software, D.O. and M.T.-S.; validation, D.O., M.T.-S., E.W. and J.L.; formal analysis, D.O., M.T.-S., E.W. and J.L.; investigation, D.O., M.T.-S., E.W. and J.L.; resources, D.O. and M.T.-S.; data curation, D.O. and M.T.-S.; writing — original draft preparation, D.O. and M.T.-S.; writing-review and editing, D.O. and M.T.-S.; visualization, D.O. and M.T.-S.; supervision, D.O.; project administration, D.O. and M.T.-S. All authors have read and agreed to the published version of the manuscript.

Funding: This research received no external funding.

Institutional Review Board Statement: Not applicable.

Informed Consent Statement: Not applicable.

Data Availability Statement: Data sharing not applicable.

Conflicts of Interest: The authors declare no conflict of interest.

\section{References}

1. Ibiza, V.P.; Blanca, J.; Cañizares, J.; Nuez, F. Taxonomy and Genetic Diversity of Domesticated Capsicum Species in the Andean Region. Genet. Resour. Crop Evol. 2012, 59, 1077-1088. [CrossRef]

2. Wang, D.; Bosland, P.W. The genes of Capsicum. Hortic. Sci. 2006, 41, 1169-1187. [CrossRef]

3. Wahyuni, Y.; Ballester, A.R.; Tikunov, Y.; de Vos, R.C.; Pelgrom, K.T.; Maharijaya, A.; Sudarmonowati, E.; Bino, R.J.; Bovy, A.G. Metabolomics and molecular marker analysis to explore pepper (Capsicum sp.) biodiversity. Metabolomics 2013, 9, 130-144. [CrossRef]

4. $\quad$ Bento, C.S.; Rodrigues, R.; Gonçalves, L.S.; Oliveira, H.S.; Santos, M.H.; Pontes, M.C.; Sudré, C.P. Inheritance of resistance to Pepper Yellow Mosaic Virus in Capsicum baccatum var. pendulum. Genet. Mol. Res. 2013, 12, 1074-1082. [CrossRef]

5. Mongkolporn, O.; Taylor, P.W.J. Wild Crop Relatives: Genomic and Breeding Resources; Springer: New York, NY, USA, 2011; Volume 5, pp. 43-57.

6. Mahasuk, P.; Chinthaisong, J.; Mongkolporn, O. Differential resistances to anthracnose in Capsicum baccatum as responding to two Colletotrichum pathotypes and inoculation methods. Breed. Sci. 2013, 63, 333-338. [CrossRef] [PubMed]

7. Yoon, J.B.; Park, H.G. Trispecies bridge crosses, (Capsicum annuum $\times$ C. chinense) $\times$ C. baccatum, as an alternative for introgression of anthracnose resistance from C. baccatum into C. annuum. Hortic. Environ. Biotechnol. 2005, 46, 5-9.

8. Soler, S.; Debreczeni, D.E.; Vidal, E.; Aramburu, J.; López, C.; Galipienso, L.; Rubio, L. A new Capsicum baccatum accession shows tolerance to wild-type and resistance-breaking isolates of Tomato Spotted Wilt Virus. Ann. Appl. Biol. 2015, 167, 343-353. [CrossRef]

9. Costa, L.V.; Lopes, R.; Lopes, M.T.G.; de Figueiredo, A.F.; Barros, W.S.; Alves, S.R.M. Cross Compatibility of Domesticated Hot Pepper and Cultivated Sweet Pepper. Crop Breed Appl. Biotechnol. 2009, 9, 37-44. [CrossRef]

10. Monteiro, C.E.S.; Pereira de Campos, K. Reproductive characterization of interspecific hybrids among Capsicum species. Crop Breed Appl. Biotechnol. 2011, 11, 241-249. [CrossRef]

11. Yoon, J.B.; Yang, D.C.; Do, J.W.; Park, H.G. Overcoming two post-fertilization genetic barriers in interspecific hybridization between Capsicum annuum and C. baccatum for introgression of anthracnose resistance. Breed. Sci. 2006, 56, 31-38. [CrossRef]

12. Martins, K.C.; Pereira, T.N.S.; Souza, S.A.M.; Rodrigues, R.; Amaral Junior, A.T.D. Crossability and Evaluation of Incompatibility Barriers in Crosses between Capsicum Species. Crop Breed Appl. Biotechnol. 2015, 15, 139-145. [CrossRef]

13. Olszewska, D.; Niklas-Nowak, A.; Nowaczyk, P. Estimation of genetic divergence within androgenic regenerants of (Capsicum annuи $\mathrm{L}$. ATZ1 $\times$ C. frutescens) $\mathrm{F}_{1}$ plants using Random Amplified Polymorphic DNA markers. BioTechnologia 2017, 3, 175-182. [CrossRef]

14. Nei, M.; Li, W.H. Mathematical model for studying genetic variation in terms of restriction endonucleases. Proc. Natl. Acad. Sci. USA 1979, 76, 5269-5273. [CrossRef]

15. Costa, F.R.; Pereira, T.N.S.; Vitoria, A.P.; Campos, K.P.; Rodrugues, R.; Silva, D.H.; Pereira, M.G. Genetic diversity among Capsicum accessions using RAPD markers. Crop Breed Appl. Biotechnol. 2006, 6, 18-23. [CrossRef]

16. Orenthung, N.; Sapu, C. RAPD marker assisted study on genetic diversity of Indigenous Chilli (Capsicum sp.) landraces of Nagaland, India. Int. J. Bio-resour. Stress Manag. 2013, 4, 009-013.

17. Shi, Y.H.; Hu, N.B. Acquisition, identification and analysis of an interspecific Capsicum hybrid (C. annuum $\times$ C. chinense). J. Hortic. Sci. Biotechnol. 2015, 90,31-38.

18. Ilbi, H. RAPD markers assisted varietal identification and genetic purity test in pepper, Capsicum annuum. Sci. Hortic. 2003, 97, 211-218. [CrossRef]

19. Bhadragoudar, M.R.; Patil, C.G. Assessment of genetic diversity among Capsicum annuum L. Genotypes using RAPD markers. Afr. J. Biotechnol. 2011, 10, 17477-17483.

20. Tilahun, S.; Paramaguru, P.; Bapu, J.R.K. Genetic diversity in certain genotypes of chilli and paprika as revelated by RAPD and SSR analysis. Asian J. Agric. Sci. 2013, 5, 25-31. 
21. Ahmed, M.S. Inter-simple sequence repeat (ISSR) markers in the evaluation of genetic polymorphism of Egyptian Capsicum L. hybrid. Afr. J. Biotechnol. 2013, 12, 665-669.

22. Ou, L.; Zou, X. Inter simple sequence repeat analysis of genetic diversity of five cultivated pepper species. Afr. J. Biotechnol. 2012, $11,752-757$.

23. Thul, S.T.; Darokar, M.P.; Shasany, A.K.; Khanuja, S.P.S. Molecular profiling for genetic variability in Capsicum species based on ISSR and RAPD markers. Mol. Biotechnol. 2012, 51, 137-147. [CrossRef] [PubMed]

24. Shapturenko, M.N.; Tarutina, L.A.; Mishin, L.A.; Kilchevsky, A.V.; Khotyleva, L.V. DNA divergence as a criterion of a sweet pepper (Capsicum annuum L.) selection for heterosis. Russ. J. Genet. 2014, 50, 123-130. [CrossRef]

25. Sikora, B.; Nowaczyk, P. Application of RAPD technique for identification of interspecific hybrids from genus Capsicum. Acta Sci. Pol. Hortorum Cultus 2014, 13, 155-166. 